Article

\title{
Low-Carbon Energy Governance: Scenarios to Accelerate the Change in the Energy Matrix in Ecuador
}

\author{
Flavio R. Arroyo M. ${ }^{1,2, * \mathbb{C}}$ and Luis J. Miguel ${ }^{1,3}$ (D) \\ 1 Systems Engineering and Automatic Control, School of Industrial Engineering, Paseo del Cauce s/n, \\ University of Valladolid, 47011 Valladolid, Spain; ljmiguel@eii.uva.es \\ 2 Faculty of Engineering, Physical Sciences and Mathematics, Av. Universitaria, Central University of Ecuador, \\ Quito 170129, Ecuador \\ 3 Research Group on Energy, Economy and System Dynamics, School of Industrial Engineering, \\ Paseo del Cauce s/n, University of Valladolid, 47011 Valladolid, Spain \\ * Correspondence: flavio.arroyo@gmail.com
}

Received: 5 August 2020; Accepted: 9 September 2020; Published: 11 September 2020

\begin{abstract}
This article describes the results of a study of Ecuador's energy status, using the system dynamics methodology to model supply, demand and $\mathrm{CO}_{2}$ emissions scenarios for the year 2030 . Primary energy production increased in the different projected scenarios, with oil as the most important source of energy. The increase observed in final energy consumption was mainly associated with the transport and industry sectors. A reduction in energy intensity was projected for the different scenarios, which could be associated with the projected economic growth. The results obtained were used to build a proposal for energy policies aimed at mitigating emissions. The proposed changes to the national energy matrix could be the factors that will contribute most to the achievement of carbon emission reductions projected by the different scenarios; changes in the energy matrix are mainly associated with the development of projects to replace fossil fuels with renewable energies, mainly hydropower.
\end{abstract}

Keywords: climate change; environmental sustainability; low-carbon energy; energy governance; energy policy; renewable energy

\section{Introduction}

As more and more extreme weather events occur across the world, global climate risks are intensifying. In recent years, most meteorological phenomena have been blamed for global warming [1]. The impacts of global warming generate large investments in the global economy, mainly for developing countries with little capacity to generate foreign exchange [2,3].

To prevent substantial changes in ecosystems from occurring, global $\mathrm{CO}_{2}$ emissions must decrease significantly by 2030. Although the intensity of the production of greenhouse gases has been reduced to some extent, this decrease is not taking place quickly enough to achieve a transition towards environmentally sustainable production and consumption, which favors an increase in the level of carbon emissions and the acceleration of climate change [1].

According to information from the United Nations, the latest estimates attribute seven million deaths to air pollution, which is currently one of the main general risk factors for human health worldwide, overtaken by problems of high blood pressure, diabetes and smoking [4].

Global energy-related $\mathrm{CO}_{2}$ emissions increased by $1.7 \%$ in 2018 and reached a historical maximum of $33.1 \mathrm{Gt}$ [5]; this growth contrasts with reduction commitments to meet the objectives of the Paris 
Agreement on climate change. The use of renewable energy in the production of electrical energy in the United States has contributed to a reduction in emissions [6].

Between 1989 and 2014, the use of fossil fuels remained constant, the demand for oil decreased by $6 \%$, while the consumption of natural gas and coal increased by $2 \%$ and $3 \%$, respectively. Bioenergy covers $10 \%$ of the world's energy demand [7].

The global energy demand worldwide grew by $2 \%$ in 2017, according to preliminary estimates by the International Energy Agency (EIA), more than double the growth rate in 2016. According to the 2019 edition of BP's Energy Outlook which analyzed a scenario of energy consumption by 2040, the world will demand 17,865.82 Mtoe [5]. The growth in energy consumption from 1996 to 2007 reached almost $58 \%$ and the projection made by BP foresees an increase of $32 \%$ by 2040 .

India and China are the countries with the highest growth in energy demand in the world [8]. Transparent energy policies regulate the power generation capacity of nations [9]. The increase in energy demand is focused on improving living conditions and global economic development.

In 2018, world economic growth remained stable at around 3\% [1]; between 2017 and 2018, high-income economies expanded at a constant rate of $2 \%$, while upper-middle income economies in the East and South Asian regions followed a relatively strong growth path with an average growth of $5.7 \%[10]$.

Prospects for global macroeconomic development must urgently take concrete political action to achieve sustained economic growth sustainably. The investigations of [11-20] establish that energy consumption is related to economic growth.

The efforts of an international collective action aimed at the administration and distribution of energy resources, as well as the provision of energy services in the form of global energy governance, have been proposed to provide a clear picture of the challenges related to energy use [21].

In recent years, energy governance has become an important and new field of research in international studies. It has sought to understand how the energy sector is regulated, for whom and with what consequences. Energy security uses indicators for governance. The related research has used quantitative indicators for topics such as quality of government, competition, transparency among others [9,22-24]. Indicators have been established in the energy sector to be used in energy governance. [25] This establishes energy policies related to planning and development, energy tariffs and subsidies as effective indicators of governance.

There are other important quantitative indicators to understand the context of the energy system and the options available to reduce future carbon emissions. These include basic factors such as the population wealth and the climate of the city along with energy indicators: the price of energy in each city and the relative proportion of any tax or levy; the carbon intensity of fuels the objectives established by each city for the reduction in greenhouse gas emissions; the annual energy demand [26].

An analysis of energy consumption and economic growth in Ecuador conducted by [27] indicated that, until the 1970s, the country mainly had an agro-export model; by 1937, a transition had begun that led to an oil-producing model in the country. At that time, oil production was more than three times higher than oil consumption which led to significant changes in the country's technification.

Ecuador is an oil-producing country; as its financial resources are limited, investment in renewable energy has focused on hydroelectric energy. Ecuador has important challenges regarding the exploitation of its natural resources and the conservation of its ecosystems [8].

The main oil fields in Ecuador are in the Amazon region, where biodiversity and the fragility of ecosystems impose technical and economic challenges in relation to their exploitation. For a long time, the natural gas associated with oil production was ventilated and burned instead of being utilized, releasing significant amounts of $\mathrm{CO}_{2}$ and other pollutants into the atmosphere [8].

By world standards, Ecuador's oil industry is relatively modest; its proven oil reserves are approximately 8000 million barrels [28]. Despite this modest classification, the oil sector plays a prominent role in the country's economic policy and welfare, representing about $50 \%$ of export earnings and about a third of all fiscal revenues. Clean energies have had a minimal contribution in the primary 
energy matrix, except for hydroelectric energy production, which increased by $115 \%$ between 2000 and 2016 [29]. The total final energy production between 2000 and 2016 maintained a regularity of around $71,000 \mathrm{KBOE}$. It is important to highlight how, from 2014, electricity became the main final energy source in Ecuador [30].

Global warming is palpable in Ecuador; in recent years, there has been a reduction of about $40 \%$ in the glaciers of the Chimborazo, Cotopaxi and Antisana volcanoes [8]. To address this problem, since 2012, the 'Climate Change Strategy', developed by the Ministry of Environment and socialized within municipalities, has been implemented. The plan includes three aspects: adaptation, mitigation and a reduction in emissions from deforestation [31].

Renewable energies have become the fastest growing energy source, representing about a quarter of the global electricity generation [32]. Their participation is expected to grow as there is an increase in the electrification of the end-use sectors [33]. Since 2016, electricity has generated greater investments than the oil and gas sectors [34].

The costs of producing renewable energy have decreased, becoming a major driver of change. In the last 10 years, the average cost of electricity generated from photovoltaic and wind solar energy decreased by more than $70 \%$ and $20 \%$, respectively. By 2020, the average cost of electricity generated by solar and wind sources will be the lowest on the market [35]. This competitive advantage is the result of technological progress and increased investment in this sector. Hydropower and geothermal energy have also shown competitive costs since they have started to operate [36].

Several countries are switching to renewable energy because they want to be less dependent on imports of energy from oil and gas. Several of the major oil-producing countries have set targets to increase renewable energy generation. The United Arab Emirates, by 2050, expect $44 \%$ of their energy mix to be made up of renewable energy and a 70\% reduction in their carbon emissions [36].

Renewable energies bring macroeconomic advantages; the expectations for 2050 are that the cost of production will go from $5 \%$ to $2 \%$ of the world GDP [37]. To achieve energy and decarbonization goals, countries promote the use of renewable energy and energy efficiency $[38,39]$.

Energy and climate change policies should not be complicated and clean energy must be provided at a competitive cost aimed at reducing emissions [40]; it is necessary to review and reorient fuel subsidies and direct funds towards developing new technologies to mitigate environmental problems, and countries must plan energy transition policies that promote the use of renewable energy [41]. The European Union has proposed policies for an energy transition focused on reducing emissions, developing clean energy and energy efficiency [42].

It is necessary to develop a coherent and comprehensive governance system that can address general sustainability constraints and implement long-term objectives [43]. Designing a coherent energy and climate policy will require a clear political objective that aims to reduce carbon emissions and adapt the energy system to the impacts of climatic variability and change [27,44]; this energy policy must be based on research to enable the proper planning, decision making, implementation and evaluation of its objectives.

This article describes and tests an approach for estimating energy production, final energy demand and proposed energy policing aimed at reducing $\mathrm{CO}_{2}$ emissions in a newly integrated assessment framework that focuses on the biophysical and economic dimensions and interactions that arise during energy transitions. System dynamics is a perspective and set of conceptual tools that enable us to understand the structure and dynamics of complex systems, as well as a modelling method that enables us to build formal computer simulations of complex systems [45].

\section{Materials and Methods}

This section describes the methodology we developed to estimate the final energy supply and demand for the sector in Ecuador. A method has been developed based on the top-down projection of the evolution of final energy demand by the economic sector. The input-output analysis is based on a matrix that describes the supply and demand of energy between different sectors. Its combination with 
environmental aspects allow us to assign a specific final energy consumption per unit of monetary production to each sector in the search for low-carbon energy governance.

\subsection{Model Description}

This research has a two-part methodology that includes a literature review and evaluation and a scenario analysis using system dynamics (SD). System dynamics originated in control engineering and automation to determine a structure with different, interrelated input and output flows to fill or drain (respectively) different stocks. Two variables, connected by a causal link, can change in the same direction (positive relationship) or in opposite directions (negative relationship). In a positive-or reinforcing-feedback loop, growth in the first variable causes growth in the second variable, but growth in the second variable also causes growth in the first variable [46].

$\mathrm{SD}$ analyzes complex socio-ecological systems and is considered a feasible resource for thinking about sustainable futures [45]. SD models are used to simulate dynamic behavior over time [46]. SD is recreated by the explicit mapping of information transfers between stocks and flows to model feedback interactions [47]. The energy perspective is an indispensable tool to determine and analyze the most probable future scenarios for an energy system. Future energy demand and composition scenarios have implications for political decisions [48].

The system dynamics methodology has been widely used to model complex systems in which feedback, delays, and nonlinearities are frequent $[47,49]$. Some of these applications have been aimed at modelling energy and environmental systems $[45,50,51]$, as well as integrated evaluation models $[5,6]$. From all the analyses of the literature review, it is understood that low-carbon energy governance will help accelerate the shift to a sustainable energy matrix in Ecuador. The historical data series used in the research was taken from the information collected from the national energy balances [29,52-55].

\subsection{Scenario Analysis}

Our design shows the energy perspective and the production of $\mathrm{CO}_{2}$ emissions in Ecuador. Three scenarios were developed to show the relationship between the energy mix, economic growth and emissions in Ecuador. The design of these scenarios allows us to predict the evolution of the variables and, in turn, helps to generate energy policies and project the reduction in $\mathrm{CO}_{2}$ emissions.

The Business as Usual (BAU) scenario projects past trends and those that will continue [49]. The National Policies (NP) scenario proposes the prioritization of the use of renewable energy sources, promotes the use of hydroelectric energy and replaces inefficient thermal generation. The massive implementation of efficient lighting in homes and public roads is proposed. This scenario also suggests the replacement of equipment with newer models that have a higher energy consumption. The replacement of LPG with electricity is proposed, with the implementation of induction cookers and execution of energy management systems in the main industries. The scenario also promotes the realization of a sustainable transport system that uses electricity and not hydrocarbons as the main source of energy; it also raises energy sovereignty as one of the pillars of a new energy matrix. The Global Policies and Trends (GPAT) scenario considers multilateral environmental agreements and global macroeconomic prospects for sustainable development, and replacement strategies for clean energy and energy efficiency. It considers the projections or trends of the reports of organizations such as the Intergovernmental Panel on Climate Change (IPCC), International Energy Agency (IEA), and BP, among others.

\subsection{Modelling and Simulation}

The model is divided into four main modules: economy, energy demand, energy availability, and climate/emissions. The conceptual schematic description includes the main relationships between the different modules. The main characteristics of each module are: 
- Economy: the economy is modeled, assuming demand-driven growth and the complementarity of the sector. Therefore, production is determined by final demand and economic structure, combined with supply-side constraints, such as energy availability.

- Energy demand: final energy demand by sector is estimated through the projection of sector economic production and sector final energy demand, considering efficiency improvements and inter-final energy replacements driven by policies and physical scarcity.

- Energy availability: this module includes the potential and availability of RES and non-renewable energy resources, considering the biophysical and temporal limitations. In particular, the availability of non-renewable energy resources depends on both stock and flow limitations. In total, 5 energy sources and technologies are considered, and 9 final energies (electricity, solids, gases and liquids), with a technological breakdown. The modeling of energy availability is mainly based on the previous WoLiM model [56].

- Climate/emissions: the global model calculates the levels of $\mathrm{CO}_{2}$ emissions generated by the final amount of energy used in Ecuador.

The evolution and integration of the model across modules requires, for each time step, the energy demand and supply to be balanced dynamically. The system was designed to establish energy policies and $\mathrm{CO}_{2}$ emissions in Ecuador in 2030. The traditional energy resources of the country are also considered. The impact of economic growth on energy consumption and $\mathrm{CO}_{2}$ emissions is analyzed. The flowchart of the economic-energy-carbon emissions system is shown in Figure 1. The energy consumption of each of the economic sectors generates $\mathrm{CO}_{2}$ emissions.

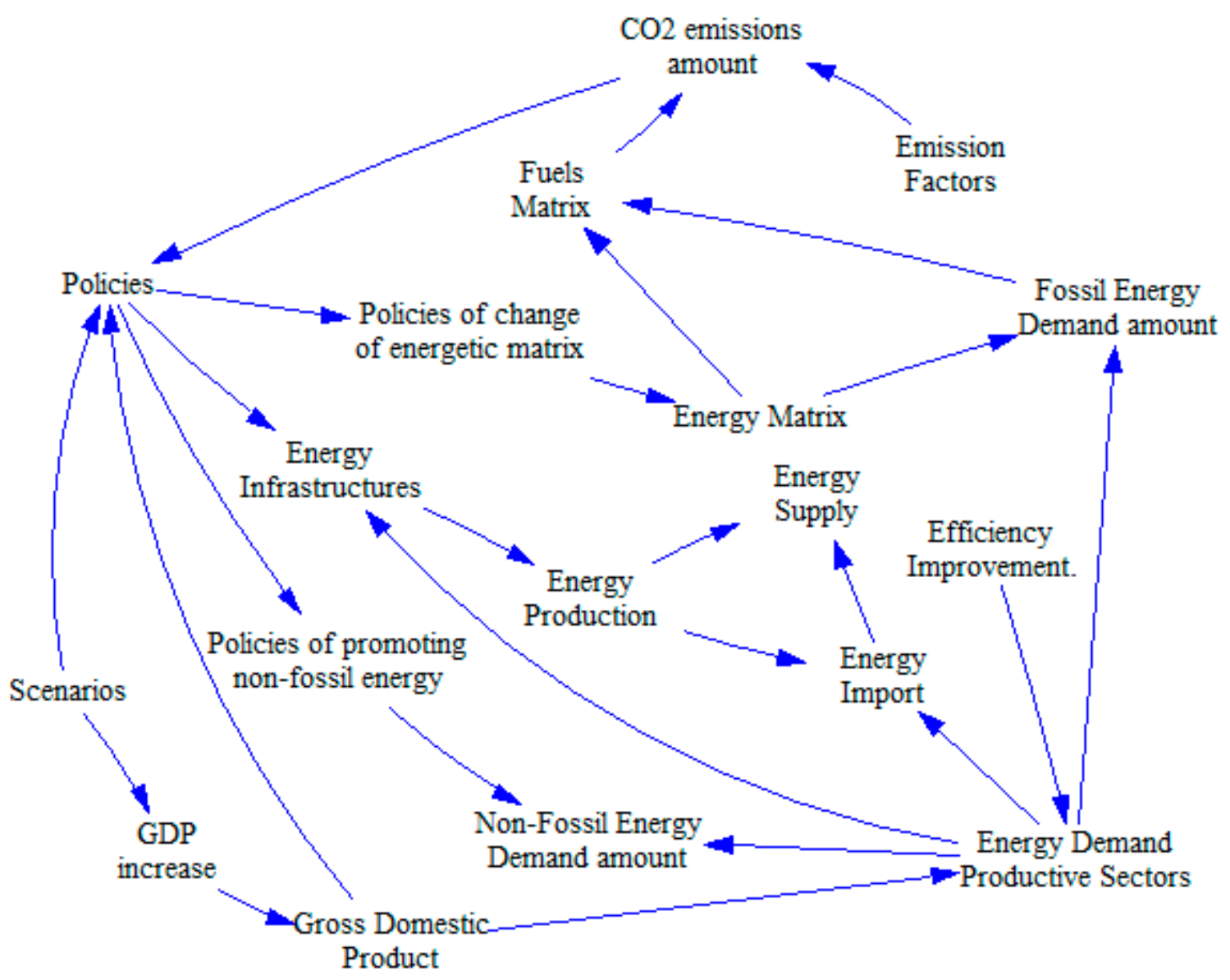

Figure 1. Flow diagram of the energy system and production of carbon emissions in Ecuador (adapted from [18]). 


\section{Results}

The results obtained in order to simulate the scenarios of supply and demand for energy and the production of $\mathrm{CO}_{2}$ emissions in 2030 are shown in Table 1. In all the projected scenarios, an increase in primary energy production is observed; this increase is greater in the NP and GPAT scenarios because these scenarios consider energy exploitation and production policies. In the NP scenario, energy policies continue with oil exploitation and the construction of new hydroelectric projects [57].

Table 1. Results obtained through the dynamics model for different energy variables and $\mathrm{CO}_{2}$ emissions for 2016 and the Business as Usual (BAU), National Policies (NP) and Global Policies and Trends (GPAT) scenarios for 2030 .

\begin{tabular}{ccccc}
\hline \multirow{2}{*}{ Variables } & \multicolumn{3}{c}{ Simulated Scenarios to 2030 } \\
\cline { 2 - 5 } & $\mathbf{2 0 1 6}$ & BAU & NP & GPAT \\
\hline Primary energy production (KBOE) & $117,987.00$ & $151,219.00$ & $225,901.00$ & $195,145.00$ \\
Final energy demand (KOB) & $86,400.80$ & $184,345.00$ & $134,193.00$ & $103,521.00$ \\
PIB per capita (USD 2007 per habitant) & 4355.61 & 6223.09 & 6648.99 & 6283.12 \\
$\mathrm{CO}_{2}$ emissions (KT CO $\mathrm{CO}_{2}$ ) & $36,073.50$ & $75,182.60$ & $43,938.30$ & $42,191.40$ \\
Carbon emissions per capita (TCO 2$)$ & 2.20 & 3.89 & 2.33 & 2.46 \\
Carbon emissions/GDP (kgCO $/ \mathrm{TSD}_{2}$ 2007) & 0.51 & 0.63 & 0.35 & 0.39 \\
Energy intensity (BEP thousands USD 2007) & 1.21 & 1.51 & 1.07 & 0.96 \\
\hline
\end{tabular}

A breakdown of primary energy production by sector can be seen in Figure 2, revealing that obtaining energy from oil is the most important source in all the scenarios considered. However, a significant increase in the contribution of energy from hydroelectric sources and natural gas can be observed. Ecuador's energy mix was mainly based on the use of non-renewable sources; the use of renewable energy generation technologies is the least developed and is related to the launch of large-capacity hydroelectric plants, as their greater participation is expected.



Figure 2. Primary energy production, Business as Usual (BAU), National Policies (NP) and Global Policies and Trends (GPAT) scenarios for 2030.

An increase in final energy demand by 2030 can be observed (Table 1). This will increase by 3.3 times in the BAU scenario if the current characteristics of energy consumption are maintained, which projects high and inefficient consumption. Maintaining current consumption habits would require Ecuador to significantly increase energy production; one should even consider importing hydrocarbons due to the incredibly high national energy demand. The lower projections raised by 
the PN (National Policies (NP) scenario) and PYTM (Global Policies and Trends scenario (GPAT)) scenarios, reducing the energy demand by 2.6 and 1.8 times, respectively, could be associated with a government policy to replace energy sources and improve energy efficiency. The BAU scenario projection shows a final energy demand of 184,345 KBOE. The NP and GPAT scenarios project an energy demand of 134,193 and 103,521 KBOE, respectively; this is due to the higher efficiency of electrical energy (Figure 3).

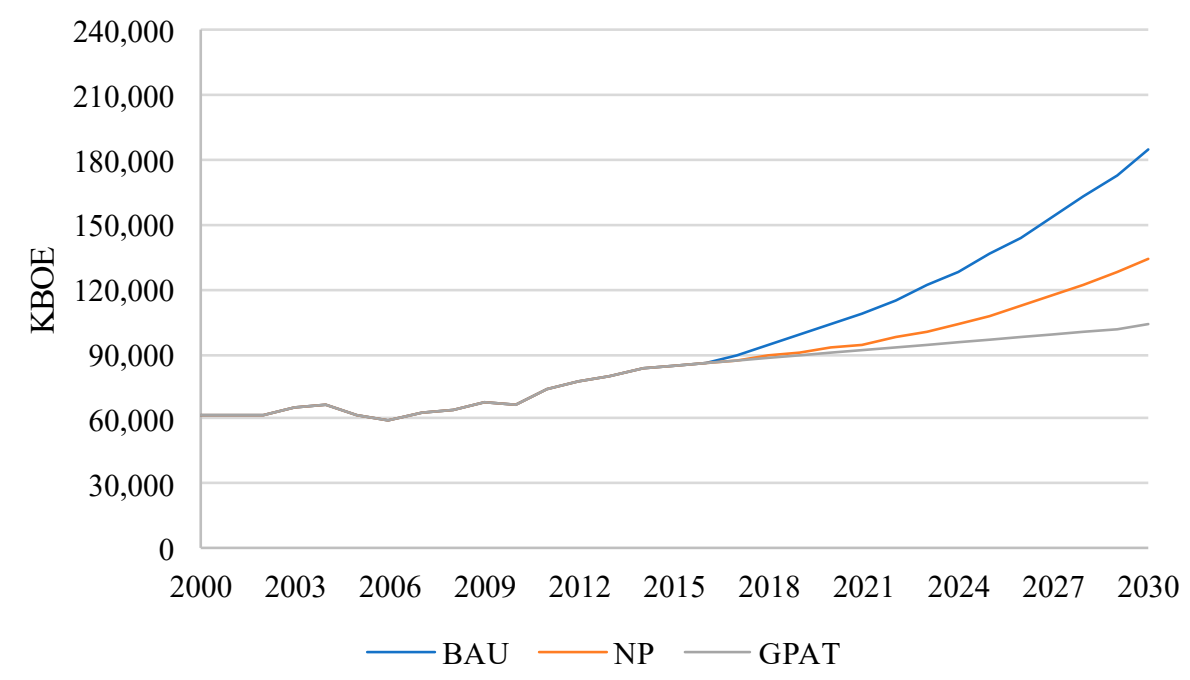

Figure 3. Energy demand, Business as Usual (BAU), National Policies (NP) and Global Policies and Trends (GPAT) scenarios for 2030.

A more exhaustive analysis of final energy consumption indicates, for the National Policies scenario (NP) and Global Policies And Trends scenario (GPAT), that 20\% and 54\%, respectively (Figure 4), of the total use would be in the transport sector, a sector that has been characterized by its inefficiency in the use of energy, mainly due to its use of fossil fuels.

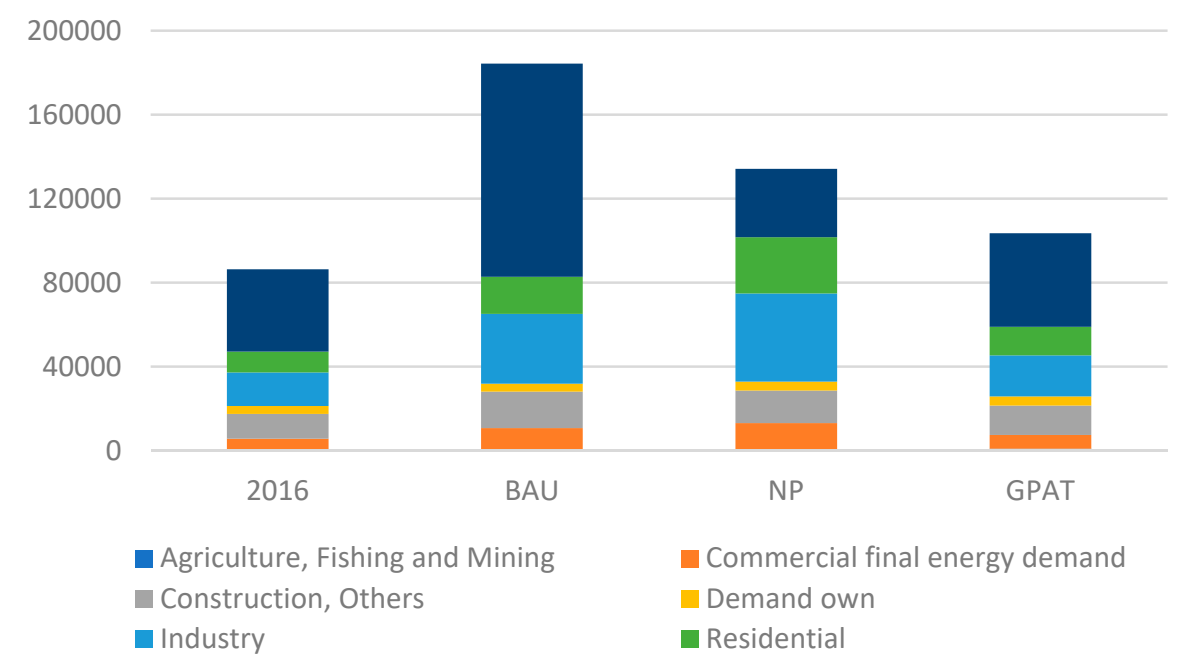

Figure 4. Distribution of energy demand by sector for 2016 and the Business as Usual (BAU), National Policies (NP) and Global Policies and Trends (GPAT) scenarios for 2030.

The projected reduction in relation to the BAU scenario is probably the result of the promotion of the use of biofuels and the use of electricity in mass passenger transport nationwide. Another sector that shows an increase in final energy consumption is the industrial sector, for which an energy transition has been proposed-a change in production equipment. 
The projection of the model for GDP per capita foresees increases of $128 \%$ and $123 \%$ for the National Policies scenario (NP) and Global Policies and Trends scenario (GPAT) (Table 1); however, economic growth would be relatively low, even for a region, as currently the average region value is USD 9270, and Ecuador barely reaches half that value. Currently, the GDPs of North America exceed USD 58,000 and the GDPs of the European Union exceed USD 33,000. The projections for 2030 foresee a moderate growth worldwide and this would only amplify the gap that Ecuador must solve; therefore, a structural change in the economy focused on sustained and equitable long-term economic growth is essential [58].

The proposed changes in the national energy matrix and the substitution of the type of energy could be the factors that contribute most to the achievement of a reduction in carbon emissions projected by the National Policies (NP) and Global Policies And Trends (GPAT) scenarios (Table 1). In relation to the maintenance of exaggerated current trends, emissions in the BAU scenario will increase by 2.7 times by 2030. If Ecuador does not implement measures in relation to consumption and energy sources, $\mathrm{CO}_{2}$ emissions will continue to increase, especially if it does not adopt the use of more efficient and less pollutant energies, not like those currently used, which are mostly of fossil origin. The implementation of measures for the proposed scenarios would favor reductions of $44 \%$ and $38 \%$ in the ratio of $\mathrm{CO}_{2}$ emissions to GDP for the National Policies (NP) and Global Policies And Trends (GPAT) scenarios compared to the increase observed for the BAU scenario by 2030 (Table 1).

The energy intensity projections for the National Policies (NP) scenario and Global Policies and Trends scenario (GPAT) project a reduction in relation to the current values as well as an expected increase for the BAU scenario (Table 1). [59] It has been proposed that economic growth goes hand in hand with the efficient use of energy and, in the Ecuadorian case, changes in the energy matrix have been contemplated mainly due to the development of projects for the replacement of fossil fuels, with renewable energy being represented by hydroelectric energy. Ecuador mainly presents inefficiency indicators in the transportation and industry sectors [29]; if current conditions are maintained, Ecuador will continue to be an inefficient nation in relation to energy use.

\section{Discussion}

Considering the simulation results, Ecuador shows an energy inefficiency in the transportation and industry sectors. Using the BAU, National Policies (NP) and Global Policies and Trends (GPAT) scenarios for 2030, we can analyze the energy policies that will serve as the basis for the design of energy governance aimed at mitigating emissions and improving national energy efficiency. These three scenarios allow us to establish the effects of energy governance and environmental sustainability on Ecuador through appropriate energy policies.

After examining the role of the world's leading institutions in the area of energy governance, intergovernmental organizations create multilateral banks and global action networks. Existing forms of global governance coincide with the scope of the global energy challenges. The urgency of effectively implementing global energy policies to address nations' geopolitical tensions and economic changes compels researchers to investigate global energy governance [21,60]. The efforts of international collective action aimed at the administration and distribution of energy resources, as well as at the provision of energy services in the form of global energy governance, could provide a clear picture of the energy-related challenges.

Energy efficiency seeks to reduce energy waste and expenses along the energy chain, reduce dependence on energy imports, mitigate damage to the environment and improve a country's productive efficiency. Effective energy efficiency intervention requires several strategic actors in the energy industry, including consumers and authorities [61].

When considering scenarios with better economic prospects and lower energy consumption, energy intensity tends to be reduced, which reduces the amount of $\mathrm{CO}_{2}$ emissions. By increasing the proportion of renewable energy, we can see how this reduces $\mathrm{CO}_{2}$ emissions. 
Fossil fuels are the main source of energy consumption in Ecuador. Efforts to improve Ecuador's energy efficiency have not achieved the expected results, making it urgent to improve the energy efficiency of different sectors, which would contribute to reducing expenses throughout the energy chain, reducing emissions and improving the country's productivity. A reduction in $\mathrm{CO}_{2}$ emissions is feasible if the use of an energy mix is considered, utilizing Ecuador's hydroelectric potential and other renewable sources.

Ecuador has begun a transformation in the energy sector, departing from a dependence on fossil fuels for electricity generation to complete self-sufficiency through hydroelectric power. The country is also improving its energy transfer infrastructure to allow the more efficient transportation of massive high-voltage loads.

Considering Ecuador's hydroelectric potential, the combination of a higher proportion of hydroelectric power and other renewable sources would allow a smaller amount of $\mathrm{CO}_{2}$ emissions to be generated. Finally, there are projections that consider that increases in the share of hydroelectric power by $50 \%$ and $70 \%$ would result in a decrease in carbon emissions to 27.36 and $15.03 \mathrm{MtCO}_{2}$, respectively, instead of the 37.10 MTons currently projected, which shows that the road to follow is the one with the greatest use of renewable energy [57].

Transportation growth is inevitable; therefore, transportation management must be optimized. In this sector, it is necessary to improve the quality of fuels. The replacement of inefficient or obsolete technologies under new projects by using energy from renewable sources is essential. The use of passenger transport should be promoted, as well as the substitution of fuels to modify energy intensity due to its higher level of efficiency.

In the industrial sector, it is necessary to change the energy sources used, and this sector must migrate towards renewable energies. Inefficient equipment such as motors, pumps or boilers must be replaced; cogeneration systems must be included, and energy management systems must be applied.

National policies for the efficient use of energy in buildings must be regulated and created, based on habitability criteria, to promote the replacement of high-energy consumption equipment, optimize public lighting, and strengthen the energy efficiency program for induction cooking and heating water, which does not use fossil fuels.

A variety of responses have been noted in the literature when analyzing the relationship between economic growth and $\mathrm{CO}_{2}$ emissions for different countries; some studies have indicated that economic growth has a causal relationship with the variation in $\mathrm{CO}_{2}$ emissions $[17,18,20,62-67]$. Other studies indicate that there is a two-way relationship between economic growth and $\mathrm{CO}_{2}$ emissions. In the last two years, the global economy has grown, according to a report by the International Energy Agency (IEA); however, $\mathrm{CO}_{2}$ emissions have not increased at all, indicating that there is no clear link between economic growth and the growth in $\mathrm{CO}_{2}$ emissions $[1,68]$.

The relationship between $\mathrm{CO}_{2}$ emissions and economic growth makes it possible to formulate energy policies and promote the use of renewable energy resources [69-71]. Research has allowed us to realize that, currently, in developed economies, the influence of economic growth on $\mathrm{CO}_{2}$ emissions is lower. On the other hand, in developing countries, this relationship remains strong because economic growth is prioritized over environmentally friendly production processes, but this approach does not consider the type of resources used or the effects that will appear in the future.

\section{Conclusions}

Greater investment in the development of renewable energy projects would contribute to the mitigation of $\mathrm{CO}_{2}$ emissions and lead to better care of our environment for future generations [27]. After performing an energy analysis, we found that, between 1979 and 2015, in Ecuador, economic growth was promoted by energy consumption, particularly by economic growth in the primary, secondary and tertiary economic sectors, and that there is a causal relationship that associates the consumption of oil and hydroelectricity with economic growth. 
The increase in energy consumption in Ecuador affects the economic situation of the country; large subsidies are granted in relation to the consumption of electrical energy. Ecuador is an exporter of crude oil and an importer of petroleum derivatives, both of which generate expenses for the national government. To achieve a more sustainable development dynamic, the price of petroleum-based energy should be increased, especially when used for unproductive activities, while the consumption of renewable energy, especially oriented to the industrial sector, should be subsidized.

A scenario of significant economic growth would allow for investment in projects related to the mitigation of $\mathrm{CO}_{2}$ emissions. In order to achieve sustainable economic growth and maintain a good relationship with our ecosystem, the growth of production and the commercialization of products must be accompanied by investments in constant improvements in all economic activities to reduce pollution to the minimum amount possible in Ecuador.

Economic projections do not predict encouraging scenarios for Ecuador, so it is necessary to establish energy policies that improve the wellbeing of Ecuadorians. On the other hand, if we consider the scenarios that preview greater economic growth and the use of renewable energy, we will realize that, over time, this relationship is not as close as in the past. The economic recovery of Ecuador and the promotion of greater investments in innovation and technological development will be necessary in the fight to mitigate $\mathrm{CO}_{2}$ emissions and take care of our environment for the future generations.

To achieve sustainable economic growth and maintain a good relationship with our ecosystem, the growth of production and the marketing of products must be accompanied by investments in constant improvements in all economic activities to reduce pollution to the minimum amount possible. Maintaining the policies that have been implemented and incorporating others will allow Ecuador to maintain progressive economic development, which currently aims to invest in new technologies and in projects focused on the use of clean energy and caring for the environment. Replacing non-renewable energy with clean energy and designing energy policies focused on climate change must go hand in hand, projecting a more encouraging image for the future of $\mathrm{CO}_{2}$ emissions in Ecuador.

Author Contributions: Investigation F.R.A.M.; conceptualization, F.R.A.M. and L.J.M.; methodology, F.R.A.M. and L.J.M.; software, F.R.A.M. and L.J.M.; writing—original draft preparation F.R.A.M.; writing-review and editing F.R.A.M. and L.J.M.; supervision L.J.M.; validation L.J.M. All authors have read and agreed to the published version of the manuscript.

Funding: This research received no external funding.

Conflicts of Interest: The authors declare no conflict of interest.

\section{References}

1. United Nations Environment Programme. Global Environment Outlook GEO-6: Healthy Planet; UN Environment: Nairobi, Kenya, 2019.

2. Claussen, E.; Peace, J. Energy myth twelve-climate policy will bankrupt the US economy. In Energy and American Society-Thirteen Myths; Springer: Dordrecht, The Netherlands, 2007; pp. 311-340.

3. Stern, N. The Economics of Climate Change; Cambridge University Press: Cambridge, UK, 2007.

4. International Energy Agency. Energy and Air Pollition; International Energy Agency: Paris, France, 2016.

5. BP. BP Statistical Review of World Energy; Pureprint Group Limited: London, UK, 2019.

6. International Energy Agency. Global Energy \& CO2 Status Report; IEA: Paris, France, 2018.

7. International Energy Agency. World Energy Outlook; IEA: Paris, France, 2016.

8. Arroyo, F.R.; Miguel, L.J. Analysis of energy demand scenarios in Ecuador: National government policy perspectives and global trend to reduce $\mathrm{CO}_{2}$ emissions. Int. J. Energy Econ. Policy 2019, 9, 364-374.

9. Ren, J.; Sovacool, B.K. Quantifying, measuring, and strategizing energy security: Determining the most meaningful dimensions and metrics. Energy 2014, 76, 838-849. [CrossRef]

10. World Bank Group. Global Economic Prospects; The World Bank: Washington, DC, USA, 2019.

11. Chang, C.-C. A multivariate causality test of carbon dioxide emissions, energy emissions, energy consumption and economic growth in China. Appl. Energy 2010, 87, 3533-3537. [CrossRef] 
12. Zhang, X.-P.; Cheng, X.-M. Energy consumption, carbon emissions, and economic growth in China. Ecol. Econ. 2009, 68, 2706-2712. [CrossRef]

13. Saboori, B.; Sulaiman, J. $\mathrm{CO}_{2}$ emissions, energy consumption and economic growth in Association of Southeast Asian Nations (ASEAN) countries: A cointegration approach. Energy 2013, 55, 813-822. [CrossRef]

14. Pao, H.-T.; Tsai, C.-M. $\mathrm{CO}_{2}$ emissions, energy consumption and economic growth in BRIC countries. Energy Policy 2010, 38, 7850-7860. [CrossRef]

15. Mirzaei, M.; Bekri, M. Energy consumption and $\mathrm{CO}_{2}$ emissions in Iran, 2025. Environ. Res. 2017, 154, 345-351. [CrossRef] [PubMed]

16. Hasseb, M.; Azam, M. Energy consumption, economic growth and $\mathrm{CO}_{2}$ emission nexus in Pakistan. Asian J. Appl. Sci. 2015, 8, 27-36. [CrossRef]

17. Saidi, K.; Hammami, S. The impact of $\mathrm{CO}_{2}$ emissions and economic growth on energy consumption in 58 countries. Energy Rep. 2015, 1, 62-70. [CrossRef]

18. Arroyo, F.; Miguel, L.J. The Trends of the Energy Intensity and $\mathrm{CO}_{2}$ Emissions Related to Final Energy Consumption in Ecuador: Scenarios of National and Worldwide Strategies. Sustainability 2019, 12, 20. [CrossRef]

19. Gazheli, A.; Van den Bergh, J.; Antal, M. How realistic is green growth? Sectoral-level carbon intensity versus productivity. J. Clean. Prod. 2016, 129, 449-467. [CrossRef]

20. Arroyo, M.F.R.; Miguel, L.J. The Role of Renewable Energies for the Sustainable Energy Governance and Environmental Policies for the Mitigation of Climate Change in Ecuador. Energies 2020, 13, 3883. [CrossRef]

21. Florini, A.; Sovacool, B.K. Who governs energy? The challenges facing global energy governance. Energy Policy 2009, 37, 5239-5248. [CrossRef]

22. Sovacool, B.K. An international assessment of energy security performance. Ecol. Econ. 2013, 88, 148-158. [CrossRef]

23. Sovacool, B.K.; Mukherjee, I.; Drupady, I.M.; D’Agostino, A.L. Evaluating energy security performance from 1990 to 2010 for eighteen countries. Energy 2011, 36, 5846-5863. [CrossRef]

24. Saunders, H.; Sovacool, B.K. Competing policy packages and the complexity of energy security. Energy 2014, 67, 641-651.

25. Ang, B.; Choong, W.; Ng, T. Energy security: Definitions, dimensions and indexes. Renew. Sustain. Energy Rev. 2015, 42, 1077-1093. [CrossRef]

26. Morlet, C.; Keirstead, J. A comparative analysis of urban energy governance in four European cities. Energy Policy 2013, 61, 852-863. [CrossRef]

27. Pinzón, K. Dynamics between energy consumption and economic growth in Ecuador: A granger causality analysis. Econ. Anal. Policy 2018, 57, 88-101. [CrossRef]

28. BP. Statistical Review of World Energy; BP: London, UK, 2017.

29. Coordinating Ministry of Strategic Sectors. National Energy Balance 2016; Coordinating Ministry of Strategic Sectors: Quito, Ecuador, 2017.

30. Coordinating Ministry of Strategic Sectors. National Energy Agenda 2016-2040; Coordinating Ministry of Strategic Sectors: Quito, Ecuador, 2016.

31. Sosa, G.F. El Cuidadano Períodico Oficial. 15 Noviembre 2017. Available online: http://www.elciudadano.go b.ec/ecuador-implementa-programas-para-reducir-las-emisiones-de-gases-contaminantes/ (accessed on 30 June 2019).

32. IRENA. Renewable Energy Statistics 2018; International Renewable Energy Agency: Masdar City, UAE, 2018.

33. International Energy Agency. World Energy Outlook 2018; IEA Publications: Paris, France, 2018.

34. International Energy Agency. World Energy Investment; IEA Publications: Paris, France, 2018.

35. IRENA. Renewable Power Generation Costs in 2017; International Renewable Energy Agency: Masdar City, UAE, 2018.

36. Global Commission on the Geopolitics of Energy Transformation. A new world. In The Geopolitics of the Energy Transformation; International Renewable Energy Agency: Masdar City, UAE, 2019.

37. DVG.GL. Energy Transition Outlook 2018; DVG.GL: Oslo, Norway, 2018.

38. Downie, C. Business actors, political resistance, and strategies for policymakers. Energy Policy 2017, 108, 583-592. [CrossRef]

39. Simsek, Y.; Lorca, Á.; Urmee, T.; Bahri, P.A.; Escobar, R. Review and assessment of energy policy developments in Chile. Energy Policy 2019, 127, 87-101. [CrossRef] 
40. Helm, D. The European framework for energy and climate policies. Energy Policy 2014, 64, 29-35. [CrossRef]

41. Chang, C.-C.; Carballo, C.F.S. Energy conservation and sustainable economic growth: The case of Latin America and the Caribbean. Energy Policy 2011, 39, 4215-4221. [CrossRef]

42. Gao, M.-Z.A.; Fan, C.-T.; Liao, C.-N. Application of German energy transition in Taiwan: A critical review of unique electricity liberalisation as a core strategy to achieve renewable energy growth. Energy Policy 2018, 120, 644-654. [CrossRef]

43. Hildingsson, R.; Johansson, B. Governing low-carbon energy transitions in sustainable ways: Potential synergies and conflicts between climate and environmental policy objectives. Energy Policy 2016, 88, 245-252. [CrossRef]

44. Emodi, N.V.; Chaiechi, T.; Rabiul, A.B.M.; Beg, A. A techno-economic and environmental assessment of long-term energy policies and climate variability impact on the energy system. Energy Policy 2019, 128, 329-346. [CrossRef]

45. De Blas, I.; Miguel, L.J.; Capellán-Pérez, I. Modelling of sectoral energy demand through energy intensities in MEDEAS integrated assessment model. Energy Strategy Rev. 2019, 26, 100419. [CrossRef]

46. Nieto, J.; Carpintero, Ó.; Miguel, L.J.; De Blas, I. Macroeconomic modelling under energy constraints: Global low carbon transition scenarios. Energy Policy 2020, 137, 111090. [CrossRef]

47. Sterman, J.D. Business dynamics. In Systems Thinking and Modeling for a Complex World; McGraw-Hill Higher Education: New York, NY, USA, 2000.

48. Mondal, M.A.H.; Bryan, E.; Ringler, C.; Mekonnen, D. Ethiopian energy status and demand scenarios: Prospects to improve energy efficiency and mitigate GHG emissions. Energy 2018, 149, 161-172. [CrossRef]

49. Meadows, D.H.; Meadows, D.L.; Randers, J.; Behrens, W.W. The Limits to Growth; Universe Books: New York, NY, USA, 1972.

50. Ford, A. Modeling the Environment, 2nd ed.; Island Press: Washington, DC, USA, 2010.

51. Sterman, J.; Fiddaman, T.; Franck, T.R.; Jones, A.; McCauley, S.; Rice, P.; Sawin, E.; Siegel, L. Climate interactive: The C-ROADS climate policy model. Syst. Dyn. Rev. 2012, 28, 295-305. [CrossRef]

52. Coordinating Ministry of Strategic Sectors. National Energy Balance 2013; Coordinating Ministry of Staging Sectors: Quito, Ecuador, 2013.

53. Coordinating Ministry of Staging Sectors. National Energy Balance 2014; Coordinating Ministry of Staging Sectors: Quito, Ecuador, 2014.

54. Coordinating Ministry of Strategic Sectors. National Energy Balance 2015; Coordinating Ministry of Staging Sectors: Quito, Ecuador, 2015.

55. Ministry of Energy and Non-Renewable Natural Resources. National Energy Balance 2017; Ministry of Energy and Non-Renewable Natural Resources: Quito, Ecuador, 2018.

56. Capellán-Pérez, I.; Mediavilla, M.; De Castro, C.; Carpintero, Ó.; Miguel, L.J. Fossil fuel depletion and socio-economic scenarios: An integrated approach. Energy 2014, 77, 641-666. [CrossRef]

57. CONELEC. Electrification master plan 2013-2022; CONELEC: Quito, Ecuador, 2013.

58. Calderón, Á.; Dini, M.; Stumpo, G. Los Desafíos del Ecuador Para el Cambio Estructural con Inclusión Social; Naciones Unidas: Santiago, Chile, 2016.

59. Everett, T.; Ishwaran, M.; Ansaloni, G.P.; Rubin, A. Economic Growth and the Environment; Department for Environment, Food and Rural Affairs: London, UK, 2010.

60. Kunchornrat, J.; Phdungsilp, A. Multi-Level Governance of Low-Carbon Energy Systems in Thailand. Energies 2012, 5, 531-544. [CrossRef]

61. Limaye, D.R.; Heffner, G.C.; Sarkar, A. An Analytical Compendium of Institutional Frameworks for Energy Efficiency Implementation; The World Bank Group: Washington, DC, USA, 2008.

62. Munir, Q.; Lean, H.H.; Smyth, R. $\mathrm{CO}_{2}$ emissions, energy consumption and economic growth in the ASEAN-5 countries: A cross-sectional dependence approach. Energy Econ. 2020, 85, 104571. [CrossRef]

63. Acheampong, A.O. Economic growth, $\mathrm{CO}_{2}$ emissions and energy consumption: What causes what and where? Energy Econ. 2018, 74, 677-692. [CrossRef]

64. Xue, B.; Geng, Y.; Muller, K.; Lu, C.; Ren, W. Understanding the Causality between Carbon Dioxide Emission, Fossil Energy Consumption and Economic Growth in Developed Countries: An Empirical Study. Sustainability 2012, 6, 1037-1045. [CrossRef]

65. Nain, M.Z.; Ahmad, W.; Kamaiah, B. Economic growth, energy consumption and $\mathrm{CO}_{2}$ emissions in India: A disaggregated causal analysis. Int. J. Sustain. Energy 2015, 36, 807-824. [CrossRef] 
66. Hossain, M.S. Panel estimation for CO2 emissions, energy consumption, economic growth, trade openness and urbanization of newly industrialized countries. Energy Policy 2011, 39, 6991-6999. [CrossRef]

67. Piłatowska, M.a.G.A.; Włodarczyk, A. The Effect of Renewable and Nuclear Energy Consumption on Decoupling Economic Growth from $\mathrm{CO}_{2}$ Emissions in Spain. Energies 2020, 13, 2124. [CrossRef]

68. Kosow, H. Methods of Future and Scenario Analysis: Overview, Assessment, and Selection Criteria; German Development Institute (DIE): Bonn, Germany, 2008.

69. Ahmed, M.M.; Shimada, K. The Effect of Renewable Energy Consumption on Sustainable Economic Development: Evidence from Emerging and Developing Economies. Energies 2019, 12, 2954. [CrossRef]

70. Mardani, A.; Streimikiene, D.; Nilashi, M.; Aranda, D.A.; Loganathan, N.; Jusoh, A. Energy consumption, economic growth, and $\mathrm{CO}_{2}$ emissions in $\mathrm{G} 20$ countries: Application of adaptive neuro-fuzzy inference system. Energies 2018, 11, 2721. [CrossRef]

71. Mardani, A.; Streimikiene, D.; Cavallaro, F.; Loganathan, N.; Khoshnoudi, M. Carbon dioxide $\left(\mathrm{CO}_{2}\right)$ emissions and economic growth: A systematic review of two decades of research from 1995 to 2017. Sci. Total. Environ. 2019, 649, 31-49. [CrossRef]

(C) 2020 by the authors. Licensee MDPI, Basel, Switzerland. This article is an open access article distributed under the terms and conditions of the Creative Commons Attribution (CC BY) license (http://creativecommons.org/licenses/by/4.0/). 